\title{
Leucaena leucocephala, White Leadtree ${ }^{1}$
}

\author{
Michael G. Andreu, Melissa H. Friedman, and Robert J. Northrop ${ }^{2}$
}

Warning: white leadtree is a category II invasive species in Florida, and its possession, transport, and cultivation is strictly prohibited by the Florida Division of Plant Industry.

\section{Family}

Fabaeceae, legume or pea family

\section{Genus}

The genus name Leucaena comes from the Greek words leuc meaning "white" and caen meaning "new" or "recent," and refers to the whitish flowers this tree produces each year.

\section{Species}

The species name leucocephala comes from the Greek words leuc meaning "white" and cephal meaning "head." Like the genus name, the species name also refers to the whitish flowers that the tree produces each spring, but it also alludes to the fact that the blossoms are in clusters or "heads" around the tree.

\section{Common Name}

\section{White leadtree, Lead tree, Jumbie bean}

Lead tree is the common name for all members of the Leucaena genus. White leadtree refers to this particular tree's whitish blossoms and reflects the scientific name. The name "jumbie bean" refers to the word jumbey, and is in reference to the name of a disease acquired by animals that eat certain parts of the tree.

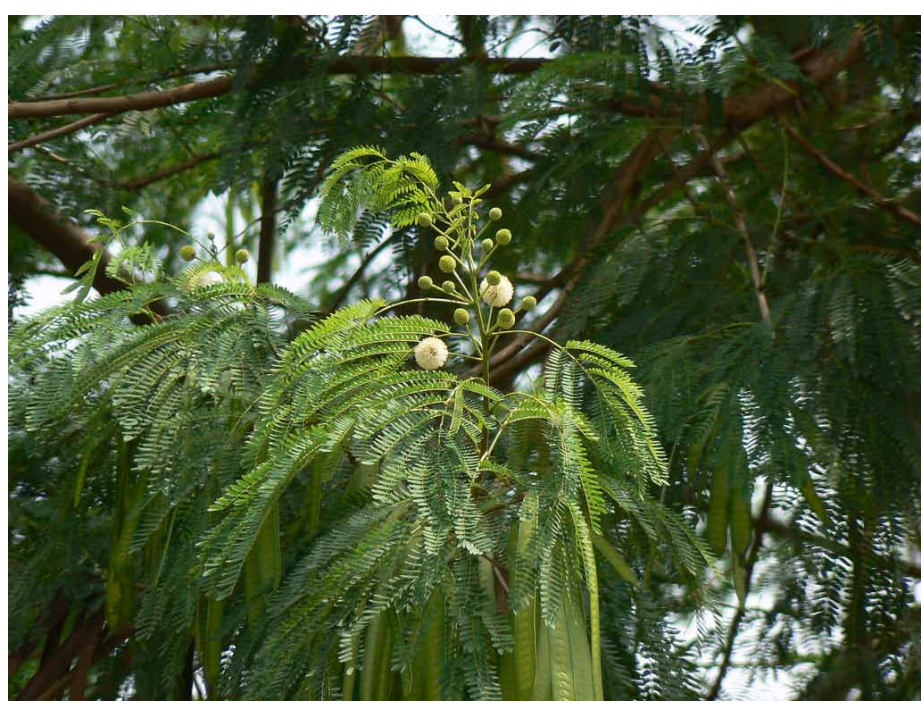

Figure 1. White leadtree (Leucaena leucocephala) Credits: Dinesh Valke, CC BY-NC-ND 2.0, http://flic.kr/p/34RxzU

\section{Description}

This evergreen tree is native to Mexico and Central America, but it can also be found in California, Arizona, Texas, Florida, the Virgin Islands, and other tropical regions of the world. In its native range, it typically inhabits grassy hammocks and areas with sandy, well-draining soil, while elsewhere it emerges in a multitude of dry-to-mesic disturbed sites. White leadtree grows best in full sunlight and can reach heights of up to 60 feet. The leaves are alternately arranged, bipinnately compound, and typically 10 inches in length. Each leaflet is $1 / 2$ inch long and spear-shaped. The bark is lightly textured and grayish-brown in color when mature. Flowers are white and grow in globe-shaped clusters at the ends of the branches, with each cluster being

1. This document is FOR299, one of a series of the School of Forest Resources and Conservation, Florida Cooperative Extension Service, Institute of Food and Agricultural Sciences, University of Florida. Original publication date July 2012. Visit the EDIS website at http://edis.ifas.ufl.edu.

2. Michael G. Andreu, associate professor; Melissa H. Friedman, research scientist; School of Forest Resources and Conservation; and Robert J. Northrop, Extension forester, Hillsborough County Extension; University of Florida, Gainesville, Florida 32611. 
less than 1 inch wide. Fruits are 4- to 6-inch-long, flat pods that are 1-2 inches wide. Pods have raised edges, turn from green to brown with maturity, and contain $10-30$ ovalshaped, brown seeds.

\section{Applications}

\section{Commercial/Practical}

In Florida, white leadtree is a prohibited species and therefore is not used in commercial applications in the

state. However, in its native range it is used as a source of charcoal, fuel, and lumber. It has also been planted as a windbreak for crops such as coffee and cocoa, and some ranchers use the tree as a source of both shade and forage for cattle, with the pods being an excellent source of protein. In addition, as white leadtree forms a well-developed taproot, it has been planted to assist with erosion control.

\section{Cultural}

In the Caribbean islands, the seeds are strung together to make necklaces. In other locations, the pods and roasted seeds are a source of food.

\section{Horticultural}

In Florida, white leadtree is considered a category II invasive species, and has the potential to displace native plant communities because it is an aggressive competitor for resources. As a result, the Division of Plant Industry strictly prohibits possessing (including collecting), transporting (including importing), and cultivating this species. In its native range, however, white leadtree is planted as a shade tree.

\section{Medicinal}

While the bark can be made into tonics that reportedly heal stomach maladies, ingestion of other parts of the tree can cause infertility, hair loss, and other symptoms of a disease that West Indians call "jumbey."

\section{Wildlife}

Birds and rodents benefit from eating the high-protein seeds, but they also act as dispersing agents of the seeds.

\section{Additional References}

University of Florida Center for Aquatic and Invasive Plants (2009). Lead tree. http://plants.ifas.ufl.edu/node/224.

USDA Plants Database (n.d.). Leucaena leucocephala (Lam.) de Wit. http://plants.usda.gov/java/profile?symbol=LELE10. 